\title{
前立腺癌の酵素学的研究
}

V. 前立腺マツサージに伴う血清 phosphatase, leucine aminopeptidase 活性值の経時的変動について

広島大学医学部泌尿器科学教室 石 部 知行
(主任: 仁平寛已教授)

\section{ENZYMOLOGICAL STUDY OF PROSTATIC CANCER V.}

Alterations in the Serum Acid and Alkaline Phosphatase and Leucine

Aminopeptidase Activities Following Massage of the Prostate

Tomoyuki Ishibe

From the Department of Urology, Hiroshima University School of Medicine, Hiroshima

(Director: Prof. H. Nihira)

A study was performed on the alterations with time of the serum alkaline phosphatase, total acid phosphatase, prostatic acid phosphatase and leucine aminopeptidase activities following massage of the prostate in patients with carcinoma or benign hyperplasia of the prostate having a premassage control activities of a definite range. The statistical significance of the results obtained were tested by the F-test. The results are as follows. i) Following massage of the prostate an increase of total and prostatic serum acid phosphatase activities in patients with benign hyperplasia was significantly higher than those in patients with carcinoma, and these elevations serve to differentiate between benign hyperplasia and carcinoma of the prostate. ii) Alterations after massage of the prostate, serum alkaline phosphatase and leucine aminopeptidase activities between both experimental groups all failed to show any significant changes in their behavior and level following massage of the prostate.

前立腺のマッサージを行ならと前立腺に病変のあるな しにかかわらずtotal serum acid phosphatase(以下 TSAP

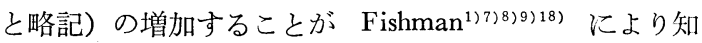
られ，また前立腺疾患，特に悪性腫瘍の診断に TSAP を測定することも広く行なわれている. しかし高い活性 を示す場合にはその診断的価値は大であるが，低い場命 には問題も多く早期診断の役にはたたないとする者も多 $\left({ }^{14)}\right.$.

一万 serum alkaline phosphatase (以下 SALP と畍 記）は肝疾患とともに骨造成性の変化に関係した骨疾患 の場合増加するとされ, 前立腺癌で骨転移のある場合々 の増加がしばしばみられ，この場合 TSAP の増加のない 場合も多いといわれている. しかしながら前立腺内での ALP はわずかに含まれるのみで，前立腺癌における意 義は明らかではなく, わずかに治療効果の判定と予後の 判定の目的に TSAP と同時に測定されているのが現状

\section{である.}

前立腺癌患者における serum leucine aminopeptidase （以下 SLAP と略記）活性の変動は肝転移との関係で 注目されているのみで, 前立腺内に打ける意義ならびに その活性についてはなお明らかではない。

本論文では比較的正常值に近い活性を示した搒断確笑 な前立腺償患者の TSAP, Protatic serum acid phosphatase (以下 PSAP と略部) ならびにSLAP, SALP活性に

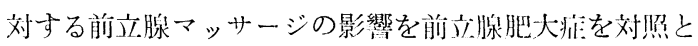
して検澍した成績を報告する。

\section{実験法}

症例は広島大学医学部附属病院泌疛器科で経験した前 立腺癌および前立腺肥大症患者であり，それぞれの症例 数ならびに平均年令は SALP については18例, 20例, $80.4(\mathrm{R}=62 \sim 83)$ 才, $67.7(\mathrm{R}=57 \sim 75)$ 才, TSAP については14例，8例， $72.1 （ \mathrm{R}=62 \sim 79 ）$ 才, 68.5 
（ $\mathrm{R}=64 \sim 77 ）$ 才, PSAP については18例, 8例, 72.9 ( $\mathrm{R}=62 \sim 83)$ 才, $69.7(\mathrm{R}=64 \sim 77)$ 才，また SLAP については10例，16例, 73.3（ $\mathrm{R}=68 \sim 74 ）$ 才, 70.7 （ $\mathrm{R}=64 \sim 77 ）$ 才であつた. これらの腎者に対し，早朝 8 時に対照值をらるべく时静脈より採血後, 直腸内より示 指でもつて, 前立腺癌では㬴瘍部分を, 前立腺肥大症に 対しては全体を5 分間強くマッサージし，マッ省ージ直

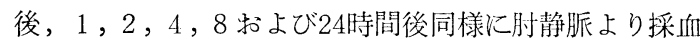
し、これを試料として值ちに酵素活性の測定を行なつた。 测定した酵素は TSAP, PSAP, SALP 拈よび SLAP で あり，その測定には TSAP，PSAP および SALP には Iatron $^{10)}$ を，また SLAP は Sigma ${ }^{20)}$ を用いたが，そ の単位は King-Armstrong units/dl な.らびに GoldbergRutenburg units $/ 0.02 \mathrm{ml}$ である.

さらに今回の実験では検查前值のバラッキを考虑し， 層化を試み，検查前值が TSAP 活性3-10 KAU/dl, PSAP 活性 1-3 KAU/dl, SALP 活性 6-15 KAU/dl および SLAP 活性 150〜 $500 \mathrm{GRU} / 0.02 \mathrm{ml}$ を示するののみを 対象として実験を行ない，得られた成績を $\mathrm{F}$ 検定でもつ て統計的に処理した.

\section{実験成績}

I. Serum alkaline phosphatase (SALP)

検查前の SALP 活性をみると前立腺肥大症は6.53土 $0.98 \mathrm{KAU} / \mathrm{dl}$ を示したのに対し，前立腺癌では8.35土 $0.79 \mathrm{KAU} / \mathrm{dl}$ とやや高いが，これらの間には $\mathrm{F}=1.696$ と有意差を認めなかつた。

マッサージに伴う変動をみるる前立腺肥大症では直後 より上昇し 8 時間後に $8.14 \pm 1.25 \mathrm{KAU} / \mathrm{dl}$ と最も高い值 を示したが，F=1.56と検査前值に対し有意の増加では なかつた，一方前立腺癌もマッサージ直後より $10.55 \pm$ $1.24 \mathrm{KAU} / \mathrm{dl}$ 之高い值を示したが，ついで減少，再度 8 眝間後に peakをもつ変動を示した。しかしこれらの変 動はいずれも比䡆的バラッキが大きく分散上有意の変化 ではなからた。

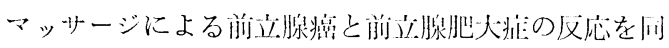
一時間でもつて $\mathrm{F}$ 検定を行なつたところ 1 時間後に $\mathrm{F}=$ 2.25ともつとも高い值を示したが，この変動は有意では なく，全経過を通じて有意の差をみとめなからた。

II. Total serum acid phosphatase (TSAP)

検查前値を比較してみると前立腺肥大症い $3.58 \pm 0.99$ $\mathrm{KAU} / \mathrm{dl}$ ，また前立腺癌は4.97士1.39KAU/dl を示した が，この両者の間には $\mathrm{F}=1.740$ と有意の差をみとめな かつた。
Table 1. The mean value with standard error of alkaline phosphatase activity in the serum following massage of the prostate in patients with prostatic carcinoma or benign prostatic hyperplasia (King-Armstrong unit/dl)

\begin{tabular}{l|c|c}
\multicolumn{1}{c|}{ Disease } & $\begin{array}{l}\text { Prostatic } \\
\text { hyperplasia }\end{array}$ & $\begin{array}{c}\text { Prostatic } \\
\text { carcinoma }\end{array}$ \\
\hline Before PM & $6.53 \pm 0.98 *$ & $8.35 \pm 0.79$ \\
\hline Immediate after PM & $7.24 \pm 1.52$ & $10.55 \pm 1.24$ \\
\hline 1 hour after PM & $7.06 \pm 1.28$ & $10.22 \pm 1.30$ \\
\hline 2 hours after PM & $7.71 \pm 2.02$ & $9.72 \pm 2.11$ \\
\hline 4 hours after PM & $7.70 \pm 2.20$ & $10.60 \pm 1.87$ \\
\hline 8 hours after PM & $8.14 \pm 1.25$ & $11.02 \pm 3.27$ \\
\hline 24 hours after PM & $7.25 \pm 2.16$ & $10.11 \pm 1.84$ \\
\hline
\end{tabular}

Note:* ; Mathematical mean \pm standard error

マッサージに伴う変動をみると前立腺肥大症では 1 時間後に8. $57 \pm 1.30 \mathrm{KAU} / \mathrm{dl}$ と peak を有し，4 時間に いたるまでの間明らかな活性の增大がみられ，これらの 変動は検查前値に対し $\mathrm{F}=5.54 \sim 6.14$ で何れも $1 \%$ の危 除摔で有意の増加であつた。

前立腺癌の前立腺マッサージに伴ら変動をみると検查 欮优は高いが逆に減少を示し，2 時間目には4.08土1.42 $\mathrm{KAU} / \mathrm{dl}$ ともつとも低い值を示し，4時間日に再びわず かながら増加した後再び低下し，24時間後には結局検査 前倠より低い活性を呈していたが，これらの变動はいず れも検查前值に対し $\mathrm{F}$ 検定上有意ではなかつた。

マッサージに伴つてみられる TSAP 活性の変動を前 立腺癌と前立腺肥大症について比較してみると, マッサ

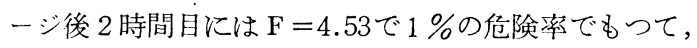
また 1 時間掞よび 4 時間目にはそれぞれ $\mathrm{F}=3.67, \mathrm{~F}=$ 3.58を示し，5\%の危険率でもつて前立腺肥大症が前立

Table 2. The mean value with standard error of total acid phosphatase activity in the serum following massage of the prostate in patients with prostatic carcinoma or benign prostatic hyperplasia (King-Armstrong unit/dl)

\begin{tabular}{c|c|c}
\multicolumn{1}{c|}{ Disease } & $\begin{array}{c}\text { Prostatic } \\
\text { hyperplasia }\end{array}$ & $\begin{array}{c}\text { Prostatic } \\
\text { carcinoma }\end{array}$ \\
\hline Before PM & $3.58 \pm 0.99$ & $4.97 \pm 1.39$ \\
\hline Immediate after PM & $4.15 \pm 0.86$ & $4.72 \pm 2.02$ \\
\hline 1 hour after PM & $8.57 \pm 1.30$ & $4.50 \pm 2.07$ \\
\hline 2 hours after PM & $8.00 \pm 3.50$ & $4.08 \pm 1.42$ \\
\hline 4 hours after PM & $7.80 \pm 3.25$ & $4.75 \pm 1.54$ \\
\hline 8 hours after PM & $4.63 \pm 1.24$ & $4.58 \pm 2.53$ \\
\hline 24 hours after PM & $3.13 \pm 0.41$ & $3.75 \pm 1.84$ \\
\hline
\end{tabular}


腺癌に対し高い活性を示していた。

Table 3. The mean value with standard error of prostatic acid phosphatase activity in the serum following massage of the prostate in patients with prostatic carcinoma or benign prostatic hyperplasia (King-Armstrong unit/dl)

\begin{tabular}{l|l|l}
\hline \multicolumn{1}{c|}{ Disease } & $\begin{array}{l}\text { Prostatic } \\
\text { hyperplasia }\end{array}$ & $\begin{array}{l}\text { Prostatic } \\
\text { carcinoma }\end{array}$ \\
\hline Before PM & $1.41 \pm 0.16$ & $2.05 \pm 0.43$ \\
\hline Immediate after PM & $2.09 \pm 0.40$ & $2.20 \pm 0.80$ \\
\hline 1 hour after PM & $6.57 \pm 0.82$ & $2.12 \pm 0.94$ \\
\hline 2 hours after PM & $5.88 \pm 0.96$ & $1.74 \pm 0.64$ \\
\hline 4 hours after PM & $5.63 \pm 0.94$ & $2.05 \pm 0.48$ \\
\hline 8 hours after PM & $2.46 \pm 0.20$ & $1.70 \pm 0.61$ \\
\hline 24 hours after PM & $0.96 \pm 0.23$ & $1.26 \pm 0.28$ \\
\hline
\end{tabular}

III. Prostatic serum acid phosphatase (PSAP)

検查前の PSAP 活性は前立腺肥大症が $1.41 \pm 0.16$ $\mathrm{KAU} / \mathrm{dl}$ を示し, 前立腺癌が $2.05 \pm 0.43 \mathrm{KAU} / \mathrm{dl}$ とやや 高い活性を示したが， F=2.48でこの両群に有意の差は みられなかつた。

マッサージに伴ら変動をみると前立腺肥大症では検査 直後より著明に増加し，1 時間目から4時間目にいたる 変動は TSAP のそれに比しやや強く, 何れ子検查前値 に対し有意の增加であつた.

Table 4. The mean value with standard error of leucine aminopeptidase activity in the serum following massage of the prostate in patients with prostatic carcinoma or benign prostatic hyperplasia (Goldberg-Rutenburg unit/0.02ml)

\begin{tabular}{l|l|l}
\hline \multicolumn{1}{c|}{ Disease } & $\begin{array}{l}\text { Prostatic } \\
\text { hyperplasia }\end{array}$ & $\begin{array}{l}\text { Prostatic } \\
\text { carcinoma }\end{array}$ \\
\hline Before PM & $351.43 \pm 70.18$ & $341.50 \pm 64.00$ \\
\hline Immediate after PM & $296.43 \pm 117.55$ & $240.50 \pm 69.64$ \\
\hline 1 hour after PM & $280.00 \pm 135.03$ & $251.53 \pm 156.35$ \\
\hline 2 hours after PM & $341.43 \pm 121.23$ & $312.05 \pm 112.61$ \\
\hline 4 hours after PM & $430.00 \pm 204.36$ & $302.56 \pm 95.38$ \\
\hline 8 hours after PM & $415.71 \pm 119.98$ & $338.33 \pm 188.79$ \\
\hline 24 hours after PM & $314.28 \pm 109.00$ & $289.01 \pm 129.89$ \\
\hline
\end{tabular}

他方前立腺癌ではマッサージ直後より全実験経過を通 じて一定の変動はなく，これらの值は検査前值に対し $\mathrm{F}=1.08 \sim 1.34$ といずれも有意の変動ではなかつた.

マッサージにともなら反応上の差は TSAP の場合と 同様で, 前立腺肥大症に扮ける $2 \sim 4$ 時間の増加は前立 腺癌に比し有意であつた.

IV. Serum leucine aminopeptidase (SLAP)

検査前值についてみると前立腺肥大症は351.43土 70 .
18GRU/0.02ml を示したのに対し，前立腺癌では341.50 $\pm 64.00 \mathrm{GRU} / 0.02 \mathrm{ml}$ と両群の間には $\mathrm{F}=1.07$ と有意差 をみとめなかつた。

マッサージによる変動をみると前立腺癌，前立腺肥大 症ともに直後より 1 時間にわたつて検査前値より低い活 性を示し，ついで増加に転じ，4～8 時間にもつとも高 い活性を示したが，検查前值に対しこれらの変動はいず れも有意ではなかつた。

またマッサージに伴なら反応上の差も両群の間汇有意 の差を認めなかつた。

\section{考 按}

わが国でも前立腺癌は平均寿命の延長と診断技術の向 上棌なつて近時増加の傾向にあるが，な打現実には手 術の適応となるような早期癌患者は Elhilali ら と米国でも5\%といわれ，また竹内 ${ }^{21}$ む初彰時すでに骨 転移をもつものが30\%もあるとし，その早期発見が望ま れるところであり，このために前立腺癌により特異的な 診断法が要求され，それらについての検討が行なわれて きた. その1つとしての血清学的診断法にも限界があ り, 現在のところ早期発見の手段としてょり, 治療効果 ないし予後判定の手段として広く用いられている. 近時 Kendall ら ${ }^{12) 18}$ とよつて前立腺マッサージが前立腺酸つ オスファターゼの血中遊出を来し診断上有用であること が知られるにいたつたが，な拈 Ziesche ${ }^{25) 26)}$ は統計的に みてその変動は有意でないとして拈り，な护問題は解決 されていない。

前立腺内に括けるALP は極めて少なく，その増減あ るいは意義に関しては十分解明されていないが，前立腺 癌で骨転移のある症例で高いことが知られ，著者ら ${ }^{11}$ む 対照に比し高いSALP 活性を示すこと，また病期の進 展に伴なつて活性の增大がみられることを明らかにして きた。

今回の SALP は活性の比較的正常と目される症例に ついての検討ではあつたが，対照とした前立腺肥大症と の間に反応上有意差はないが，何れもマッサージにより 増加の傾向を示した．さらに前立腺癌ではマッサージ直 後と 8 時間目に peak をもつ二相性の変化を示したが, この理由については明らかではない。

前立腺マッサージ後のTSAPの变動については前にも 述べたようにな打意見の一致はなく，問題のあるところ である。これは測定法，患者の撰択といつたことに原因が あると考兄られる。すなわち前立腺マッサージで確実に 
加するとするものや (17)，統計的に有意でない増加と ${ }^{25)}$ ${ }^{26)}$ いつた意見である．今回の実験は TSAP 活性が比較 的正常之目される症例，すなわち TSAP 活性の高くな く診断に困難を伴う症例についてマッサージの影響を検 討したことになるが，前立腺癌では有意の変動を示さな かつたのに対し，前立腺肥大症ではマッサージ後 $1-4$ 時間に打いて有意に TSAP 活性が增大し，この変化は 5\%の危険率でもつて有意に高かつた。 これはRoubicek and Winsten ${ }^{18)}$ の成績と一致するもので，Alken und Büscher ${ }^{224)}$ らの述べるように前立腺内に抢汁る酸 phosphatase が前立腺癌に比し前立腺肥大症で高いといらこ とと，また前立腺の大きさ ${ }^{18}$ が前立腺のもつ barrier と しての作用 ${ }^{24)}$ より大きく作用したものと解される.

一方 TSAP 活性は感度が悪く，また赤血球，肝，腎な ぞに由来するものが含まれるため3116)17724)，より前立 腺に特異的な酸フォスファターゼが検討され，Fishman ら゙は 1-tartrateを用いた PSAP 測定法を導入するとと もと PSAP 值が前立腺癌で高いとした. この PSAP が 前立腺癌に対しより有用な検査法であるとされたが5)， Whitmore ら ${ }^{14,23)}$ は早期癌の発見に対しての診断的価值 は少ないとした，今回のマッサージによる変動は TSAP の場合と同様の傾向を示し，前立腺肥大症拉よび前立腺 癌に特有な変動はみられなかつた。

非転移前立腺癌に抢ける SLAP 活性について著者ら は対照に比すればやや高いが本症に特有な変化はないと した．今回のマッサージによる変動をみると直後には活 性が低下したが，その後 4-8時間に peak をるつ活性 の増加が2られ，この変化は前立腺癌に比し前立腺肥大 症で著明であつた，前立腺癌組織における LAP 活性に ついて Kirchheim und Hodges ${ }^{13}$ 法組織化学的には腫瘍 部分では前立腺肥大症に比し低く, 腫瘍部分の周囲に高 く，その発育に関係するとしているが，Udeh ら ${ }^{19922}$ は 腺上皮の数の差にもとづく変化であり, 前立腺肥大症と 前立腺癌の間に本質的な差はないとした．このような点 から今回の成績をみるとマッサージ後前立腺癌に比し前 立腺肥大症で高い活性を示したことは TSAP などの場 合と同様に理解できるが，マッサージ直後活性がやや低 下した原因についてはなを詳らかではない。

酵素活性の測定には多かれ少なかれ技術的な誤差を生 じるもので，その範囲について Langeman ${ }^{15)}$ は土25\% とした。また同時にマッサージの様な負荷を加える実験 では対照值のバラッキも問題を複雑にするので，今回は この様なことをさけるために比較的正常值に近いと思わ
れる症例のみを取り扱つて, 得られた成績について統計 的に処理して検討する方法をとつた.

\section{結 語}

前立腺マッサージによる SALP, TSAP, PSAP および SLAP 活性の経時的変動を層化を行なつた上で, 前立 腺肥大症を対照とし, 前立腺癌のとれと $\mathrm{F}$ 検定でもつて 比較検討した結果, TSAP 活性では前立腺癌に対し前立 腺肥大症では極めて有意に活性の増大がみられ，この方 法は両者の鑑別に役立つと考学られた.PSAP の変動は TSAP の変動と本質的には同じであり, 前立腺癌に特 異な変化を示さなかつた. SALP, SLAP については有意 の変動はなく, 反応上両疾患間に有意の差をみとめなか つた.

（終るにあたり恩師仁平寬巳教授の御指導，御校閲を 感謝いたします。）

\section{文 献}

1) D'Alessandro, A. et Gilento, A.: Rass. Int. Clin. Ter., 40, 301, 1960.

2) Alken, C.E. und Büscher, H.K.: Münch. Med. Wschr., 99, 872, 1957.

3) Babson, A.L. and Read, P.A.: Amer. J. Clin. Path., 32, 88, 1959.

4) Daniel, O. and van Zyl, J.S.: Lancet, 1, 998, 1952.

5) Day, E., Ying, S.H., Schwartz, M.K., Whitmore, W.F. Jr. and Bodansky, O.: Cancer, 9, 222, 1956.

6) Elhilali, M.M., Oliver, J.A., Sherwin, A.L. and MacKinnon, K.J.: J. Urol., 98, 686, 1967.

7) Fishman, W.H., Bonner, C.D. and Homburger, F.: New Engl. J. Med., 255, 925, 1956.

8) Glenn, J.F. and Spanel, D.L.: J. Urol., 82, 240, 1959.

9) Hock, E. and Tessier, R.N.: J. Urol., 62, 488, 1949.

10) Iatron Co. Ltd.: Technical Bulletin ACP-S and ALP-S, 1970, Tokyo.

11) Ishibe, T., Nihira, H. and Mori, K.: Acta Urol. Jap., 15, 254, 1969.

12) Kendall, A.R.: J. Urol., 86, 442, 1961.

13) Kirchheim, D. und Hodges, C.V.: Urologe, 5, 69, 1966

14) Kurtz, C.W. and Valk, W.L.: J. Urol., 83, 74, 1960.

15) Langeman, H.: cited by Ziesche (1968).

16) Raabe, S.: Langenbeck's Arch. Klin. Chir., 273, 373, 1952/3.

17) Richterlich, R., Colombo, J.P. und Weber, H.: Schweiz. Med. Wschr., 92, 1496, 1962. 
18) Roubicek, M. and Winsten, S.: J. Urol., 88, 288, 1962.

19) Shigeno, T.: Jap. J. Urol., 60, 1009, 1969.

20) Sigma Co. Ltd.: Technical Bulletin No. 250, St. Louis, 1964.

21) Takeuchi, H.: J. Jap. Cancer Th., 4, 55, 1969.

22) Udeh, F.N.: Invest. Urol., 3, 413, 1966.

23) Whitmore, W.F. Jr., Bodansky, O., Schwartz,
M.K., Ying, S.H. and Day, E.: Cancer, 9, 228, 1956.

24) Woodard, H.Q.: Amer. J. Med., 27, 849, 1959.

25) Ziesche, H.W.: Z. Urol., 60, 529, 1967.

26) Ziesche, H.W.: Bruns' Beitr. Klin. Chir., 216, 250, 1968.

(1972年 3 月 1 日受付) 